\title{
Identification of striatal cell assemblies suitable for reinforcement learning
}

\author{
Carlos Toledo-Suárez ${ }^{1,2,4^{*}}$, Man Yi Yim², ${ }^{2,3}$ Arvind Kumar ${ }^{2,3}$, Abigail Morrison 1,2 \\ From Twentieth Annual Computational Neuroscience Meeting: CNS*2011 \\ Stockholm, Sweden. 23-28 July 2011
}

Both in vivo [1] and in vitro [2] experimental data suggest that medium spiny neurons in striatum participate in the formation of sequentially firing cell assemblies, at a timescale relevant for the presumed involvement of basal ganglia in reinforcement learning. Computational models argue that such cell assemblies are a feature of a minimal network architecture of the striatum [3]. This suggests that cell assemblies can be a potential candidate for representation of the 'system states' in the framework of reinforcement learning.

Spike patterns associated with cells assemblies can be identified by clustering the spectrum of zero-lag crosscorrelation between all pairs of neurons in a network [3]. Other methods based on the dimensionality reduction of the similarity matrix of the spike trains have also been used $[2,4]$.

Here we investigate how the identification of cell assemblies is dependent on the methodology chosen, and to what extent the statistical properties of the cell assemblies make them suitable for representation of system states in the striatum during reinforcement learning.

\section{Acknowledgements}

Partially funded by the German Federal Ministry of Education and Research (BMBF 01GQ0420 to BCCN Freiburg, BMBF GW0542 Cognition and BMBF 01GW0730 Impulse Control), EU Grant 269921 (BrainScaleS), Helmholtz Alliance on Systems Biology (Germany), Neurex, the Junior Professor Program of Baden-Württemberg and the Erasmus Mundus Joint Doctoral programme EuroSPIN

\section{Author details}

${ }^{1}$ Functional Neural Circuits Group, Faculty of Biology, University of Freiburg, 79104, Germany. ${ }^{2}$ Bernstein Center Freiburg, University of Freiburg, 79104, Germany. ${ }^{3}$ Neurobiology and Biophysics, Faculty of Biology, University of

\footnotetext{
* Correspondence: carlos.toledo@bcf.uni-freiburg.de

${ }^{1}$ Functional Neural Circuits Group, Faculty of Biology, University of Freiburg, 79104, Germany

Full list of author information is available at the end of the article
}

Freiburg, 79104, Germany. ${ }^{4}$ Dept. Computational Biology, School of Computer Science and Communication, KTH, Stockholm, 10044,Sweden.

Published: 18 July 2011

References

1. Miller BR, Walker AG, Shah AS, Barton SJ, Rebec GV: Disregulated information processing by medium spiny neurons in striatum of freely behaving mouse models of Huntington's disease. J Neurophysiol 2008, 100:2205-2216.

2. Carrillo-Reid L, Tecuapetla F, Tapia D, Hernández-Cruz A, Galarraga E, Drucker-Colin R, Bargas J: Encoding network states by striatal cell assemblies. J Neurophysiol 2008, 99:1435-1450.

3. Ponzi A, Wickens J: Sequentially switching cell assemblies in random inhibitory networks of spiking neurons in the striatum. J Neurosci 2010, 30(17):5894-5911.

4. Sasaki T, Matsuki N, Ikegaya Y: Metastability of active CA3 networks. J Neurosci 2007, 27(3):517-528.

doi:10.1186/1471-2202-12-S1-P228

Cite this article as: Toledo-Suárez et al: Identification of striatal cell assemblies suitable for reinforcement learning. BMC Neuroscience 2011 12(Suppl 1):P228.

\section{() Biomed Central}

Submit your next manuscript to BioMed Central and take full advantage of:

- Convenient online submission

- Thorough peer review

- No space constraints or color figure charges

- Immediate publication on acceptance

- Inclusion in PubMed, CAS, Scopus and Google Scholar

- Research which is freely available for redistribution Submit your manuscript at
www.biomedcentral.com/submit C Biomed Central 